Robert T. Ptaszek*

Lublin

\title{
Dlaczego nowa duchowość nie może być realną alternatywą dla tradycyjnej religii?
}

\section{Uwagi wstępne}

Głównym źródłem trudności, z którymi borykają się badacze nowej duchowości, jest brak definicji pozwalającej w zadowalający sposób określić to zjawisko i wyznaczyć jego granice. Sądzę, że skutecznym sposobem, który ułatwi uporządkowanie tej problematyki, okaże się zestawienie i porównanie nowej duchowości z tradycyjną religią.

W tekście ograniczam się do Europy i jej kultury. A ponieważ kultura europejska zbudowana została na fundamencie chrześcijaństwa, gdy w tych filozoficznych rozważaniach będę mówił o religii, to będzie nią właśnie chrześcijaństwo.

Współcześnie mamy do czynienia z różnymi sposobami uprawiania filozofii. Dlatego już na wstępie chcę podkreślić, że bazą dla moich rozważań jest realistyczna filozofia bytu, rozwijana przez Lubelską Szkołę Filozoficz-

* Dr hab. Robert T. Ptaszek, prof. KUL, jest kierownikiem Katedry Teorii Religii i Alternatywnych Ruchów Religijnych w Instytucie Kulturoznawstwa na Wydziale Filozofii Katolickiego Uniwersytetu Lubelskiego Jana Pawła II. Adres: Wydział Filozofii Katolickiego Uniwersytetu Lubelskiego Jana Pawła II, Instytut Kulturoznawstwa, Al. Racławickie 14, 20-950 Lublin; e-mail: rptaszek@kul.lublin.pl. 
na. O tym, dlaczego wybrałem ten nurt filozofii, pisałem już wielokrotnie ${ }^{1}$, więc tu wspomnę tylko, że o szczególnej przydatności filozofii bytu do badania nowej duchowości decyduje szeroki przedmiot jej badań, który nie ogranicza się wyłącznie do materialnego aspektu rzeczywistości. Dzięki temu za pomocą pojęć i metod filozofii bytu można gruntownie zbadać oraz ocenić koncepcje człowieka, Boga oraz łączących ich relacji i w ten sposób nie tylko opisać, ale także wyjaśnić zjawisko nowej duchowości.

Zagadnienie, które podejmuję ${ }^{2}$, stanowi kolejny etap znacznie dłuższego procesu, który najogólniej nazwać można poszukiwaniem realnej alternatywy dla chrześcijaństwa. Opis tego procesu jest skomplikowany z kilku powodów. Przede wszystkim dlatego, że poszukiwania alternatyw dla głoszonej przez chrześcijaństwo wizji świata i człowieka mają długą historię. To zrozumiałe, bo przesłanie, które przyniósł światu Jezus Chrystus, było wyjątkowe i już od chwili jego ogłoszenia budziło kontrowersje ${ }^{3}$. Nie dziwi zatem zbytnio fakt, że od początku chrześcijaństwu towarzyszyły spory o to, jak należy je właściwie rozumieć i realizować.

Drugim szczególnie ważnym źródłem problemów są kwestie terminologiczne. Pojęcia „religia” i „duchowość” rozumie się dziś na różne sposoby.

${ }^{1}$ Zob. np.: Robert T. Ptaszek, „O potrzebie i możliwościach filozoficznej analizy zjawiska nowych ruchów religijnych”, w: Człowiek w kulturze, red. Krzysztof Łojek (Warszawa: Wyższa Szkoła Finansów i Zarządzania, 2007), 541-551; Robert T. Ptaszek, „Metafizyka wobec zjawiska alternatywnych ruchów religijnych i parareligijnych", w: Człowiek i kosmos, red. Edward Jarmoch, Andrzej W. Świderski (Drohiczyn: Drohiczyńskie Towarzystwo Naukowe, 2009), 167-180.

2 Problematyce tej poświęciłem miedzy innymi wystąpienia na konferencji Old religion and new spirituality: continuity and changes in the background of secularization (University of Tartu, Estonia, 26-29.05.2015) oraz na IV Międzynarodowym Kongresie Religioznawczym (Gdynia, 17-20.06.2015). Związane z nią kwestie przedstawiłem też w opublikowanym w języku angielskim tekście: Robert T. Ptaszek, „Philosophy on Relations Between Religion And Spirituality”, Roczniki Kulturoznawcze 3 (2015): 83-90. W artykule rozwijam najważniejsze tezy z tych tekstów.

3 Jak podaje prof. Władysław Tatarkiewicz, doktryna chrześcijańska „streszczała się w trzech pojęciach [...] poznanie, prawo, zapowiedź, mianowicie poznanie Boga, prawo moralne, zapowiedź życia wiecznego" (Władysław Tatarkiewicz, Historia filozofii, t. 1 (Warszawa: Państwowe Wydawnictwo Naukowe, 1983), 173). Doktryna ta była jednak prosta tylko z pozoru, w praktyce dążenie do jej realizacji napotykało wiele trudności. W głównej mierze brały się one stąd, że zarówno sama osoba Chrystusa (wcielony Bóg), jak i nauka, którą głosił, wywołała prawdziwy przewrót w umysłach ówczesnych ludzi. Wymieńmy przykładowo kilka rewolucyjnych (czy tylko wtedy?!) myśli: traktowanie Boga jako Ojca, przekonanie, że Bóg jest miłością czy też wielokrotnie podkreślana wolność i równość wszystkich ludzi. 
O ile jednak z wieloznacznością pojęcia „religia” poradziliśmy sobie dosyć łatwo, zawężając je do jednej, wzorcowej dla naszych rozważań religii, jaką jest chrześcijaństwo, to w przypadku duchowości sytuacja jest bardziej skomplikowana. Współcześnie używa się terminu „duchowość” na określenie bardzo różnych zjawisk. Problem ten nie zniknie nawet jeśli będziemy posługiwać się węższym pojęciem, jakim jest „nowa duchowość”.

$\mathrm{Z}$ tego powodu w tekście skoncentruję się na trzech kwestiach:

1. najpierw bardzo krótko pokażę, jak przebiegały poszukiwania alternatyw dla chrześcijaństwa w europejskiej kulturze;

2. następnie wyjaśnię, czym jest duchowość i omówię rolę, jaką odgrywa w tym procesie;

3. ostatni etap to prezentacja argumentów, za pomocą których uzasadnię tezę, że nowa duchowość nie może być realną alternatywą dla chrześcijaństwa.

\section{Kilka uwag o historii poszukiwań alternatyw dla chrześcijaństwa w Europie}

Lektura obszernych, zazwyczaj liczących wiele tomów dzieł historyków Kościoła pokazuje, że przez stulecia poszukiwania alternatyw wobec chrześcijaństwa, którego głównym przedstawicielem jest Kościół katolicki, zmieniały stopniowo swoje formy. Początkowo były to przede wszystkim schizmy i herezje, które ich twórcy uważali za prawdziwe kościoły Jezusa Chrystusa. Spór między nimi a chrześcijańską ortodoksją koncentrował się zatem wokół tego, w jakiej wspólnocie religijnej powinien uczestniczyć człowiek, aby osiagnnać zbawienie. Nie kwestionowano natomiast samych fundamentów wiary.

Sytuacja zmieniła się wraz z pojawieniem się ateizmu. Trzeba pamiętać, że w naszej kulturze jest to zjawisko stosunkowo nowe - ateizm upowszechnił się w niej dopiero w XVIII wieku. A jeszcze później, bo w XIX wieku, za sprawą Ludwika Feuerbacha i kontynuatorów jego myśli próbował wykreować się na „światopogląd naukowy”, który dzięki ,światłu wiedzy” przezwycięży „religijne zabobony”.

Ateiści twierdzili, że człowiek nie jest dziełem Boga, lecz Bóg wytworem człowieka. Ponieważ w ten sposób wprost negowali chrześcijańską wizję świata, konfrontacja między ateizmem a chrześcijaństwem stała się nieunikniona. Konfrontacja ta pokazała, że - wbrew oczekiwaniom ateistów - próby eliminacji religii z ludzkiego życia nie czynią ludzi wolnymi i szczęśliwymi. 
Ponadto najnowsza historia Europy pokazuje, że próby takie wprowadzać mogą chaos do kultury.

Niepowodzenia prowadzonych w różny sposób projektów ateizacji społeczeństw, których przykładem może być porażka antyreligijnych działań komunistów w Rosji, skłoniły większość krytyków chrześcijaństwa do uznania, że istnieją takie duchowe potrzeby człowieka, które skutecznie zaspokaja tylko religia ${ }^{4}$. Za najbardziej znaczący wyraz tej postawy uznaje się dziś postulat Jürgena Habermasa ${ }^{5}$, by na nowo przemyśleć rolę religii we współczesnej kulturze Zachodu.

Nie dziwi zatem fakt, że współcześnie, oprócz tak skrajnej alternatywy wobec chrześcijaństwa, mamy do czynienia z propozycjami znacznie łagodniejszymi. Ich poszukiwania zapoczątkowane zostały w latach 60 . XX wieku przez ruch New Age. Od tego czasu mówić możemy o początkach nowej duchowości.

\section{Religia chrześcijańska a nowa duchowość}

Filozof-realista mówiąc o religii wskazuje, że w naszym kręgu kulturowym rozumie się ją jako odniesienie człowieka do Boga - a dokładniej całość wewnętrznych i zewnętrznych działań człowieka, za pomocą których oddaje Bogu cześćc . Twierdzi też, że aby uznać rzeczywisty charakter relacji religijnej, trzeba przyjąć jako prawdziwe dwie tezy:

1. istnieje Bóg,

2. człowiek to coś więcej niż tylko byt materialny - ponieważ jest istotą stworzoną przez Boga, posiada nieśmiertelną duszę.

Religia $\mathrm{w}$ takim rozumieniu jest zatem relacją między człowiekiem i Bogiem. Relacja ta ma charakter międzyosobowy - to znaczy jest rozumna, świadoma, wolna i oparta na miłości. Ponadto jest niesymetryczna - to człowiek jest „petentem”, a Bóg dawcą niezasłużonych łask. Wszystkie te cechy religii znalazły swój wyraz w definicji opracowanej przez prof. Zofię J. Zdybicką: „Religia jest realną, osobową i dynamiczną relacją człowieka

${ }^{4}$ Są to między innymi potrzeba uporządkowanej wizji rzeczywistości czy powszechnie obowiązujących norm i zasad postępowania.

${ }^{5}$ Sformułowany w jego wystapieniu z 2001 roku zatytułowanym: Wierzyć i wiedzieć.

${ }^{6}$ Według Tomasza z Akwinu istotą cnoty religijności jest „oddanie czci należnej Bogu” (Tomasz z Akwinu, Summa Theologiae [t. 19. Londyn: Veritas, 1971], II-II, 81, 2). 
do osobowego Absolutu (Boga), od którego człowiek jest zależny w istnieniu i działaniu i który jest - jako Dobro Najwyższe - ostatecznym celem życia ludzkiego, nadającym mu sens. Relacja ta wyraża się w działaniu religijnym o charakterze działań osobowych (moralnych)"’ .

Definicja ta pokazuje, że o ile przyjęcie religii jest świadomym i wolnym aktem człowieka, który sam dokonuje wyboru, uznając Boga za najwyższą wartość i przedmiot swoich dążeń, a następnie dążenia te stara się jak najlepiej wyrazić i realizować, to „podstawą zachodzenia relacji religijnej jest fakt istnienia osobowego Absolutu, w którym osoba ludzka partycypuje jako w swej przyczynie sprawczej i celowej"». Relacje, jakie zachodzą między człowiekiem i Bogiem, są więc realne - mają konieczny, a zarazem transcendentny charakter. A zatem: religia jest faktem, bo Bóg nie tylko istnieje, ale także swoje istnienie objawia czlowiekowi.

Tak rozumiana religia głosi, że śmierć nie jest końcem ludzkiego życia. Dając człowiekowi nadzieję życia wiecznego, staje się też głównym motywem jego działań.

$\mathrm{Z}$ bardziej skomplikowaną sytuacją mamy do czynienia w przypadku duchowości. Przede wszystkim samo pojęcie „duchowość” jest nieprecyzyjne, jako że dziś określamy nim bardzo różne zjawiska.

Przez stulecia w chrześcijańskiej kulturze Europy dominowała duchowość religijna. W tym czasie pojęcia „duchowość” i ,religijność” miały niemal identyczne znaczenie. Tym niemniej w chrześcijaństwie „duchowość zachowała [...] pewną odrębność, gdyż stosowano to określenie w odniesieniu do specyficznych grup, przede wszystkim monastycznych, a także do mistyków"9. Warto też pamiętać, że: „tradycja duchowości chrześcijańskiej z całym bogactwem jej odmian pozostaje ciagle żywa" ${ }^{\prime 10}$.

Oprócz duchowości chrześcijańskiej współcześnie występują co najmniej dwie inne jej formy. Pierwsza to duchowość New Age. Pojawiła się ona na przełomie lat 60. i 70. XX wieku jako rezultat zachodzacych w kulturze Zachodu przemian i inspirowanych przez nie prób znalezienia nowej tożsamości człowieka. Twórcy duchowości New Age chcieli, aby zastąpiła ona tradycyjną religię.

\footnotetext{
7 Zofia J. Zdybicka, Człowiek i religia (Lublin: Towarzystwo Naukowe KUL, 1993), 302.

8 Tamże, 303.

9 Izabela Trzcińska, O duchowości inaczej (Kraków: Uniwersytet Jagielloński, 2013), 22.

10 Tamże.
} 
New Age przyjął szerokie rozumienie duchowości, podobne do tego, które występuje w psychologii. Określał duchowość jako zdolność człowieka do stawiania pytań o to, skąd pochodzi, kim jest i dokąd zmierza oraz do podejmowania działań mających na celu jego harmonijny, psychiczno-cielesny rozwój. Toteż spopularyzowana przez ruch nowa duchowość wskazywała cele będące alternatywą dla tradycyjnych religii: zamiast zbawienia proponowała samorealizację, podkreślała też znaczenie materialnych aspektów ludzkiego życia, takich jak zdrowie, długowieczność czy harmonia z przyrodą i kosmosem. Trzeba także przyznać, biorąc pod uwagę formy, w jakich się wyrażała, że duchowość ta była w opozycji do tradycyjnej religii, stawiając praktykę przed teoria, czyli, jak to zwykło się dziś określać, przyjmując prymat ortopraksji przed ortodoksją ${ }^{11}$.

Ruch New Age uzasadniał potrzebę upowszechniania nowej duchowości, wskazując, że dotychczasowe, zinstytucjonalizowane religie nie spełniły swojej głównej roli - nie zdołały udoskonalić ludzkiej świadomości i dlatego nie były w stanie zbudować lepszego świata. Ponieważ zalecane przez tradycyjne religie praktyki nie dały oczekiwanych rezultatów, ludzie poszukujący duchowego rozwoju muszą znaleźć nowe sposoby, za pomocą których mogliby wyrażać swoje duchowe doświadczenia.

Nowa duchowość miała skutecznie wypełnić lukę po tradycyjnych religiach, ponieważ (przynajmniej według jej zwolenników) stanowiła wyższy stopień rozwoju świadomości człowieka. Wyższość ta przejawiała się w tym, że nowa duchowość nie krępowała ludzi żadną sformalizowaną religijną tradycją i nie narzucała im konkretnych dogmatów, które musieliby bezwarunkowo zaakceptować. Dzięki brakowi ograniczeń praktykujący ją ludzie mogą w bardziej kreatywny sposób szukać sensu swojego istnienia. Według twórców doktryny New Age, nowa duchowość zdolna była skutecznie zastapić tradycyjną religijność, ponieważ: „duchowość może istnieć bez religii, ale religia, prawdziwa religia, nie może istnieć bez duchowości"12.

${ }^{11}$ „W obrębie [...] Nowej Ery uważa się, że podstawą aktywności duchowej powinny być praktyki medytacyjne i oddechowe, tańce, rytuały, natomiast rola intelektualnych rozważań, spekulacji, zgłębiania teologii czy poznawania doktryny religijnej są czymś co najmniej wtórnym, a na pewno mniej ważnym” (Bartłomiej Dobroczyński, „Duchowość w kontekście Ruchu Nowej Ery", w: New Age - nowe oświecenie, red. Anna Brzezińska, Krzysztof Bondyra, Jowita Wycisk (Poznań: Wyd. Fundacji Humaniora, 1999), 35).

${ }_{12}$ Fritjof Capra, Thomas Mathus, David Steindl-Rast, Należeć do wszechświata. Poszukiwania na pograniczu nauki i duchowości (Kraków: Wydawnictwo Znak, 1995), 34. 
Nie zamierzam tu szczegółowo wchodzić w rozważania dotyczące duchowości New Age ${ }^{13}$. Chcę jedynie wskazać, że według Josepha Ratzinge$\mathrm{ra}^{14}$ charakteryzuja ją trzy cechy:

1. jest antyracjonalna (a dokładniej antymetafizyczna);

2. preferuje praktykę przed teoria,

3. jest antyosobowa - samodzielne, ,ja" traktuje jako główną przeszkodę w duchowym rozwoju człowieka ${ }^{15}$.

Pamiętając o tych cechach, łatwiej będzie zrozumieć naturę i dążenia duchowości New Age, a zwłaszcza to, dlaczego propagujący ją autorzy odwoływali się tak chętnie do religijno-mistycznych tradycji Indii i Dalekiego Wschodu.

Punktem wyjścia, a zarazem impulsem do rozwoju New Age, była fascynacja możliwościami zachodniej nauki i techniki. Ruch zaakceptował przekonanie, że są one w stanie rozwiązać niemal wszystkie problemy człowieka, dokonując równoczesnej krytyki stosowanych przez nie metod. Podstawą tej krytyki była teza, że tworzone w oparciu o zachodnią naukę technologie są szkodliwe z punktu widzenia szeroko rozumianej ekologii (obejmującej nie tylko troskę o środowisko materialne, ale także o ,środowisko duchowe"). Równocześnie twórcy ruchu byli świadomi, że przy obecnym stopniu zaawansowania zachodniej nauki i techniki zmiana takiego stanu rzeczy nie jest możliwa. Wskazywali też, że główny problem Zachodu, a zarazem źródło ograniczeń dotychczas opracowywanych technologii, stanowi materializm i będące jego konsekwencją niedocenianie sfery ducha.

${ }_{13}$ Zagadnienie to opisałem obszernie w książce: Nowa Era religii? Ruch New Age i jego doktryna - aspekt filozoficzny (Siedlce: Wyd. Akademii Podlaskiej, 2008).

${ }^{14}$ Odwołuję się do pism Josepha Ratzingera, bo jego rozważania dotyczące duchowości New Age mają raczej filozoficzny niż teologiczny charakter.

15 Warto przytoczyć nieco obszerniejszą charakterystykę głównych dążeń New Age dokonaną przez Ratzingera: „Istnieje też jednak świadomie antyracjonalna odpowiedź na doświadczenie tego, że «wszystko jest względne», która występuje pod jedną wielowarstwową nazwą New Age. Wyjścia z dylematu relatywności szukamy nie w nowym spotkaniu Ja z Ty lub z My, lecz w przekroczeniu podmiotu w ekstatycznym powrocie do kosmicznego korowodu. New Age, podobnie jak starożytna gnoza, uznaje, że jest w całkowitej harmonii ze wszystkim, o czym poucza nauka, i żąda, aby wykorzystać wszelkie poznanie naukowe (biologia, psychologia, socjologia, fizyka). Jednocześnie jednak na tym tle antyracjonalistyczny model religijny oferuje nowoczesną «mistykę»: w Absolut nie można wierzyć, lecz trzeba go doświadczyć. Bóg nie jest osobą usytuowaną poza światem, ale energią duchową przenikającą wszechświat" (Joseph Ratzinger, Wiara - prawda - tolerancja. Chrześcijaństwo a religie świata (Kielce: Jedność, 2004), 102-103). 
Aby móc skutecznie tworzyć takie technologie, które pozwolą bez szkodzenia człowiekowi oraz środowisku osiagnąć maksymalistyczne cele, zastrzeżone dotychczas dla nauki (i nieekologicznej techniki), należało znaleźć drogi pozwalające na przezwyciężenie ograniczeń zachodniego światopoglądu. Dróg tych poszukiwano w kulturach Indii i Dalekiego Wschodu. Stamtąd New Age zaczerpnął ideę przenikania się materii i ducha. Materia była przez autorów tworzących zręby nowej duchowości rozumiana jako złudzenie (maya), za którym kryje się prawdziwa, duchowa rzeczywistość. Ten idealistyczny obraz świata stał się podstawą i punktem wyjścia nowej duchowości.

Trzeba też podkreślić, że nowa duchowość kształtowała się w sytuacji specyficznego relatywizmu religijnego, który Bartłomiej Dobroczyński określił jako „dogmatyczny demokratyzm religijny”. Jego podstawę stanowi przyjęte a priori założenie o równości wszystkich tradycji religijnych ${ }^{16}$. $\mathrm{Z}$ założenia tego wynika, że istnieje wiele równoprawnych dróg duchowego rozwoju. Duchowość New Age stanowiła zatem swego rodzaju supermarket proponujący bogatą ofertę praktyk, z których każdy zainteresowany wybiera sobie to, co mu najbardziej odpowiada.

Ponieważ ruch New Age miał charakter parareligijny ${ }^{17}$, rozpoczęty przez jego przedstawicieli proces upowszechniana nowej duchowości stopniowo prowadził do jej sekularyzacji. W wyniku tego procesu pojawił się w kulturze Europy trzeci nurt duchowości, który określa się jako duchowość laicką bądź ateistyczną. Duchowość ta wypracowała całkiem nowy system odniesień, zrywając wszelkie związki ze sferą religii.

Warunkiem pozwalającym na tak kategoryczne rozdzielenie religii i nowej duchowości było ograniczenie nowej duchowości wyłącznie do sfery ludzkiej psychiki i uznanie, że głównym celem jej praktykowania ma być osiaganie przez ludzi przyjemnych i inspirujących doznań psychicznych. Wszak tego typu doznań dostarczyć może nie tylko religia, ale także na przykład obcowanie ze sztuka.

O istnieniu i popularności tej formy duchowości świadczą kolejne publikacje powstające od początku XXI wieku, takie jak chociażby wydana

16 „Wszelkie różnice między religiami mają charakter pozorny i są wynikiem odmienności w treningach kulturowych, przez jakie przeszli ich wyznawcy. Niedopuszczalne jest zatem uznawanie, że jakaś religia jest prawdziwsza od innych” (Dobroczyński, „Duchowość”, 35).

17 Ruchy religijne wskazują drogi mające doprowadzić ludzi do zbawienia (spotkania z Bogiem), a ruchy parareligijne ograniczają się do wskazywania metod doskonalenia duchowego potencjału człowieka. 
w 2006 roku książka Duchowość ateistyczna. Wprowadzenie do duchowości bez Boga ${ }^{18}$, której autorem jest francuski filozof Andre Comte-Sponville.

Wyróżnienie tych trzech rodzajów duchowości jest bardzo istotne, bo akceptacja tez o istnieniu Boga i nieśmiertelnej duszy w przypadku duchowości New Age nie jest konieczna, a w przypadku duchowości laickiej wręcz niepożądana. Powoduje to, że różnią się one zasadniczo od duchowości (i religii) chrześcijańskiej.

Podstawowa różnica sprowadza się do tego, że obie te formy nowej duchowości nie muszą kierować człowieka ku nadprzyrodzonej rzeczywistości ani być wyrazem jego religijnej wiary. Zamiast tego odnoszą się zwykle do jego subiektywnych, psychicznych odczuć. I chyba właśnie stąd wynika ich popularność - wszak sferę psychiki, pozwalającą doznawać wrażeń, odczuwać emocje i myśleć, posiada każdy człowiek.

\section{Dlaczego nowa duchowość nie może być realną alternatywą dla chrześcijaństwa}

Realistyczna filozofia bytu pokazuje, że nową duchowość trudno jest stawiać na równi z tradycyjną religią, jaką w zachodnim kręgu kulturowym jest chrześcijaństwo. Dzieje się tak, ponieważ istnieją między nimi zasadnicze różnice wynikające z tego, że:

1. Religia chrześcijańska rozwija i doskonali człowieka. Jest bowiem, jak już wspominałem, międzyosobową relacją niedoskonałego człowieka z doskonałym Bogiem, będącym dla człowieka wzorem i przewodnikiem, czyli - zgodnie z chrześcijańskim określeniem: „droga, prawdą i życiem”"19. Religia jest zatem otwarciem człowieka na doskonalszą od niego rzeczywistość. Natomiast nowa duchowość preferuje samodzielne poszukiwania człowieka, który prowadząc je zamyka się w obrębie własnego, subiektywnego świata.

2. Człowiek podążający drogą religii ma jasno określony cel. W chrześcijaństwie celem tym jest świętość. Dążący do tego celu człowiek może korzystać z pomocy duchowych przewodników oraz licznych wskazówek,

18 André Comte-Sponville, Duchowość ateistyczna. Wprowadzenie do duchowości bez Boga (Warszawa: Wyd. Czarna Owca, 2011) (L'esprit de l'atheisme. Introduction à une spiritualité sans Dieu, Paris 2006).

19 „Odpowiedział mu Jezus: Ja jestem drogą i prawdą, i życiem. Nikt nie przychodzi do Ojca inaczej jak tylko przeze Mnie" (J 14, 6). 
które pozwalają mu zorientować się, czy jest na właściwej drodze, a w razie potrzeby dokonać niezbędnych korekt w postępowaniu. Natomiast nowa duchowość skazuje człowieka na metodę prób i błędów - musi on samodzielnie poszukiwać praktyk, które pozwolą mu na osiagniecie duchowego dobrostanu. Jest to niezwykle trudne, gdyż poszukiwania te mają subiektywny charakter, a poza tym nie podlegają racjonalnej kontroli. Nowa duchowość nie bazuje bowiem na rozumie, lecz na uczuciach.

O słuszności tezy, że nowej duchowości nie sposób uznać za alternatywę dla tradycyjnej religii, świadczy również forma i jakość technik, za pomocą których usiłuje ona zastępować chrześcijańskie praktyki religijne. Aby pokazać, jak znaczące są różnice między nimi, wystarczy porównać chrześcijańską modlitwę z propagowaną przez nową duchowość medytacją.

Istnieje wiele definicji chrześcijańskiej modlitwy (określanej w języku łacińskim słowem oratio $^{20}$ ), jednak wszystkie one podkreślaja, że modlitwa jest rozmową człowieka z Bogiem. Takie znaczenie mają słowa, od których pochodzi ta nazwa - zarówno łaciński czasownik orare (mówić, prosić, błagać), jak też starosłowiańskie słowo modła (dar, ofiara, prośba). Tym, do którego zwraca się człowiek, jest „Bóg osobowy obecny i żywy [...]. Człowiek musi więc najpierw zdobyć przekonanie o Jego istnieniu i Jego bliskości"21.

Za wzorcową formę chrześcijańskiej modlitwy uznawana jest Lectio Divina, czyli duchowa lektura Pisma Świętego. Wyróżnia się w niej cztery stopnie (etapy):

- lektura,

- medytacja,

- modlitwa,

- kontemplacja.

Te cztery części stanowią spójną całość - są jakby stopniami, po których człowiek zbliża się do Boga ${ }^{22}$. Tymczasem nowa duchowość proponuje tylko jeden $\mathrm{z}$ jej etapów - medytację. A ponieważ w nowej duchowości nie występuje relacja człowiek-Bóg, przedmiotem medytacji może być wyłącznie własna świadomość człowieka.

${ }^{20}$ Na przykład św. Augustyn określa ją jako ,pobożne i pokorne zwrócenie umysłu ku Bogu”, zaś według św. Tomasza „Modlitwa jest prośbą zanoszoną do Boga o rzeczy godziwe” (Summa Theologiae, II-II, 83, 1).

${ }^{21}$ Dominik E. Wider, „Modlitwa. Studium z zakresu teologii modlitwy”, w: Postawy duchowe wobec Boga, Kościoła i człowieka, red. Marek Chmielewski (Lublin: „Polihymnia”, 1995), 157.

22 „Lektura i medytacja są dwoma etapami wstępnymi i nieodzownymi, przechodzącymi w modlitwę i kontemplację" (Tamże, 177). 
Jak zatem widać, nowa duchowość zaciera różnice między przeżyciem religijnym - na przykład stanem mistycznym - a różnymi formami jego naśladowania, ograniczającymi się zazwyczaj do wywołania silnych przeżyć emocjonalnych. Propagując techniki prowadzące do maksymalizacji ,wrażeń duchowych", nowa duchowość zdaje się zapominać, że o wartości takich doświadczeń wcale nie decyduje ich intensywność, lecz wpływ, jaki wywierają na życie człowieka. Toteż przeżycia religijne, które są udziałem chrześcijan, motywują ich do nieustannego rozwoju i dążenia do doskonałości, tak aby jak najbardziej upodobnić się do Boga ${ }^{23}$. Natomiast nowa duchowość zakłada hedonistyczne, a dokładniej konsumpcyjne, podejście do sfery ducha. Zaleca praktyki, które mająjak najmniejszym nakładem sił i środków umożliwić ludziom osiągnięcie satysfakcjonujących duchowych doznań.

Cele, do których dążą ludzie praktykujący nową duchowość, można osiagnąć także za pomocą środków (na przykład substancji psychoaktywnych), niemających wiele wspólnego z religijnymi praktykami. Najczęściej wybierane drogi, na których ludzie poszukują „duchowych atrakcji”, opisał Joseph Ratzinger:

Szukamy ekstazy, odurzenia nieskończonością, co może się przejawiać w odurzającej muzyce, w rytmie, w tańcu, w szaleństwie światła i ciemności, w masie ludzkiej. W tym przypadku neguje się tu nie tylko całą nowożytną drogę do panowania podmiotu, lecz sam człowiek - aby się zbawić - musi pozbyć się własnego Ja. Wracają bogowie, którzy stali się bardziej wiarygodni niż Bóg. Powinno się odnowić stare rytuały, w których Ja zostaje włączone w tajemnice wszechświata i uwolnione od siebie ${ }^{24}$.

Nowa duchowość stwarza więc atmosferę, która zachęca ludzi do podejmowania różnych ryzykownych doświadczeń i praktyk ${ }^{25}$. To pokazuje, jak niebezpieczne dla współczesnego człowieka mogą okazać się popularne dziś

${ }^{23}$ „Nie [mówię], że już [to] osiagnąłem i już się stałem doskonałym, lecz pędzę, abym też [to] zdobył, bo i sam zostałem zdobyty przez Chrystusa Jezusa. Bracia, ja nie sądzę o sobie samym, że już zdobyłem, ale to jedno [czynię]: zapominając o tym, co za mną, a wytężając siły ku temu, co przede mną, pędzę ku wyznaczonej mecie, ku nagrodzie, do jakiej Bóg wzywa w górę w Chrystusie Jezusie" (Flp 3, 12-14).

24 Ratzinger, Wiara, 103.

${ }_{25}$ Tym bardziej, że większość osób propagujących nową duchowość zaakceptowała pogląd Aldousa Huxley'a: ,nie ma sensu latami zajmować się medytacją czy też duchowymi ćwiczeniami, gdy wszystko można uzyskać w pół godziny za pomocą narkotyku" (podaję za: Anne Bancroft, Wspótcześni mistycy i mędrcy (Warszawa: Jacek Santorski \& Co, 2002), 24). 
postulaty, aby całkowicie oddzielić duchowość od religii. Wybór takiej opcji oznacza w najlepszym razie zgodę na zamknięcie się człowieka w sferze jego subiektywnych doznań i rezygnację z doskonalących go relacji z innymi ludźmi i z Bogiem.

Przedstawione w tekście argumenty pokazuja, że mimo licznych prób w kulturze Europejskiej dotychczas nie znaleziono dla chrześcijaństwa zadowalającej alternatywy. Uzasadniają też - jak sądzę - słuszność tezy, że na niepowodzenie skazane są także współczesne próby zastępowania chrześcijaństwa nową duchowością.

\section{Why the New Spirituality Failed to Become a Real Alternative to Traditional Religion? (Summary)}

The article is written from the point of view of realistic (classical) philosophy as proposed and developed in the Lublin Philosophical School. First, I distinguish three forms of spirituality we can see in contemporary culture of Europe. Next I present the crucial differences between the new spirituality and traditional religion (that is in our culture - Christianity). The most important source of the differences between Christianity and new spirituality is the fact that Christianity is a complex of internal and external actions by which a man worships God, whereas new spirituality does not refer to any transcendent reality, and is not a way of expressing a man's faith, but only provides experiences brightening up the human life. This is the reason why no form of new spirituality can replace the Christian religion.

Key Words: new spirituality; religion; Christianity; culture of Europe; realistic philosophy.

Dlaczego nowa duchowość nie może być realną alternatywą dla tradycyjnej religii? (Streszczenie)

Artykuł pisany jest z punktu widzenia filozofii religii rozwijanej przez Lubelską Szkołę Filozoficzną. W tekście wyróżniam i charakteryzuję trzy dominujące we współczesnej kulturze formy duchowości. Prezentuję też argumenty za tezą o zasadniczej odmienności nowej duchowości i tradycyjnej religii (czyli - w naszej kulturze - chrześcijaństwa). Najważniejszą przyczyną różnic między nimi jest fakt, 
że podstawę religii stanowi otwarcie człowieka na Boga, a jej praktykowanie jest sposobem wyrażania wiary. Natomiast nowa duchowość proponuje współczesnemu człowiekowi indywidualne poszukiwania, których celem ma być odkrywanie technik pozwalających na doświadczanie przeżyć uprzyjemniających i wzbogacających jego duchowe życie. Tak zasadnicza odmienność powoduje, że żadna z form rozwijanej współcześnie nowej duchowości nie jest w stanie stać się realną alternatywą dla chrześcijaństwa.

Słowa kluczowe: nowa duchowość; religia; chrześcijaństwo; kultura europejska; filozofia realistyczna.

\section{Bibliografia}

Bancroft, Anne. Współcześni mistycy i mędrcy. Warszawa: Jacek Santorski \& Co, 2002.

Capra, Fritjof, Thomas Mathus, David Steindl-Rast. Należé do wszechświata. Poszukiwania na pograniczu nauki i duchowości. Kraków: Wydawnictwo Znak, 1995.

Comte-Sponville, André. Duchowość ateistyczna. Wprowadzenie do duchowości bez Boga. Warszawa: Wyd. Czarna Owca, 2011.

Dobroczyński, Bartłomiej. „Duchowość w kontekście Ruchu Nowej Ery”. W: New Age-nowe oświecenie, red. Anna Brzezińska, Krzysztof Bondyra, Jowita Wycisk, 33-43. Poznań: Wyd. Fundacji Humaniora 1999.

Ptaszek, Robert T. „O potrzebie i możliwościach filozoficznej analizy zjawiska nowych ruchów religijnych". W: Człowiek $w$ kulturze, red. Krzysztof Łojek, 541-551. Warszawa: Wyższa Szkoła Finansów i Zarządzania, 2007.

Ptaszek, Robert T. Nowa Era religii? Ruch New Age i jego doktryna - aspekt filozoficzny. Siedlce: Wyd. Akademii Podlaskiej, 2008.

Ptaszek, Robert T. „Metafizyka wobec zjawiska alternatywnych ruchów religijnych i parareligijnych". W: Człowiek i kosmos, red. Edward Jarmoch, Andrzej W. Świderski, 167-180. Drohiczyn: Drohiczyńskie Towarzystwo Naukowe, 2009.

Ptaszek, Robert T. „Philosophy on Relations Between Religion And Spirituality”. Roczniki Kulturoznawcze 3 (2015), 83-90.

Ratzinger, Joseph. Wiara - prawda - tolerancja. Chrześcijaństwo a religie świata. Kielce: Jedność, 2004.

Tatarkiewicz, Władysław. Historia filozofii, t. 1. Warszawa: Państwowe Wydawnictwo Naukowe, 1983. 
Tomasz z Akwinu. Summa Theologiae, t. 19. Londyn: Veritas, 1971.

Trzcińska, Izabela. O duchowości inaczej. Kraków: Uniwersytet Jagielloński, 2013. Wider, Dominik E. „Modlitwa. Studium z zakresu teologii modlitwy”. W: Postawy duchowe wobec Boga, Kościoła i człowieka, red. Marek Chmielewski, 153-185. Lublin: „Polihymnia”, 1995.

Zdybicka, Zofia J. Człowiek i religia. Lublin: Towarzystwo Naukowe KUL, 1993. 